\title{
FARKLI BOYUTLARDA KİNOA KEPEK UNU KULLANIMININ BİSKÜVİLERİN FİZİKSEL, DUYUSAL VE TEKSTÜREL ÖZELLİKLERİ ÜZERİNE ETKİSİ
}

\author{
Hakan Erinç* \\ Niğde Ömer Halisdemir Üniversitesi, Mühendislik Fakültesi, Gıda Mühendisliği Bölümü, Niğde, Türkiye \\ Geliş / Received: 18.08.2020; Kabul / Accepted: 20.10.2020; Online bask1 / Published online: 06.11.2020
}

Erinç, H. (2020). Farklı boyutlarda kinoa kepek unu kullanımının bisküvilerin fiziksel, duyusal ve tekstürel özellikleri üzerine etkisi. GIDA (2020) 45(6)1121-1133 doi: 10.15237/gida.GD20098

Erinc, H. (2020). The effect of different sized quinoa bran flour usage on the physical, sensory and textural properties of biscuits. GIDA (2020) 45(6)1121-1133 doi: 10.15237/gida.GD20098

\section{ÖZ}

Kinoa, mükemmel besin değeri nedeniyle insan diyeti için oldukça önemlidir. Ancak, kinoanın teknolojik uygulamaları, glutensiz yapısı nedeniyle daha az ilgi görmüştür. Ayrıca kinoa yan ürünü olan kinoa kepeği esas olarak hayvan yemi olarak kullanılsa da insan sağlığı üzerinde olumlu etkisi olan potansiyel bir diyet lifi kaynağıdır. Bu çalışmada farklı boyutlarda kinoa kepek unu kullanımının bisküvilerin fiziksel, tekstürel ve duyusal özellikleri üzerine etkilerinin incelenmesi amaçlanmıştır. Bu amaçla, kinoa kepekleri değirmende 5 farklı boyutta öğütülmüș ve buğday unundan yapılmıș bisküvilere $\% 25$ oranında eklenmiștir. Elde edilen sonuçlara göre kinoa kepek ununun boyutları küçüldükçe örneklerin kuru madde oranı artış göstermiştir. Yine kepek unu boyutlarının küçülmesi ile bisküvilerin dış parlaklık değerlerinde artış gözlenmiştir. Bisküvilerin tekstür ve duyusal özelliklerinde kinoa eklenmesi sonucunda azalış belirlenmiştir. Bu çalışma farklı boyutlardaki kinoa kepek unu ile zenginleştirilen bisküvilerin özelliklerinde meydana gelen değişimleri ortaya koymuştur.

Anahtar kelimeler: Kinoa, bisküvi, tekstürel özellikler, zenginleştirme

\section{THE EFFECT OF DIFFERENT SIZED QUINOA BRAN FLOUR USAGE ON THE PHYSICAL, SENSORY AND TEXTURAL PROPERTIES OF BISCUITS}

\begin{abstract}
Quinoa is unique for a human diet due to its excellent nutritional value. However, technological applications of quinoa have received less attention because of its gluten-free nature. In addition, although quinoa bran which is by-product of quinoa flour is used mainly as animal feed, it is a potential source of dietary fiber that has a positive effect on human health. In this study, it was aimed to investigate the effects of quinoa bran flour with different particle sizes on physical, textural and sensory properties of biscuits. For this purpose, quinoa bran flours were milled to 5 different particle sizes and added to the wheat flour biscuit at a constant level (25\% of wheat flour). According to the results, the dry matter contents of the samples increased as the particle size of the quinoa bran flour decreased. Similarly, an increase in the color values of the biscuit was observed depending on the bran particle size. The textural and sensory characteristics of biscuit samples were decreased. This study reveals the changes in the properties of biscuits enriched with different sized quinoa bran flour. Keywords: Quinoa, biscuit, textural properties, enrichment
\end{abstract}

\footnotetext{
* Yazışmalardan sorumlu yazar / Corresponding author;

$\triangle$ hakanerinc@hotmail.com, $\quad(+90) 3882254005$,

且 $(+90) 3882250112$
}

Hakan Erinç; ORCID no: 0000-0001-8858-4570 


\section{GİRIŞ}

Sağllklı beslenmek isteyenler, diyet yapanlar, bazı gidalar1 tüketmesi yasaklanan hastalar veya farklı tat arayışında olup, bununla birlikte sağlığından ödün vermeyen insanlar için günden güne farklı gidalar ile karşılaşılmaktadır. Son dönemler adından sıkça bahsedilen kinoa (Chenopodium quinoa Willd.) da bunlardan bir tanesidir. Kinoa yüksek besin içeriği sayesinde dünyanın her tarafindan son dönemde dikkatleri üzerine çekmiş ve FAO tarafından kinoanın gelecek yüzyılda gıda güvencesinin sağlanmasına yönelik bitkilerden olduğu kabul edilmiştir (Koyun, 2013).

Ülkemizdeki birçok market raflarında yer alan kinoa ürünleri beslenmede önemli yeri olan protein, diyet lifi, esansiyel yağ asitleri, mineraller ve vitaminlerce zengin olmalarının yanı sıra iyi bir enerji kaynağı olmaları kinoayı yaygin olarak kullanılan tahıl çeşitlerinden farklı kılmaktadır. (Valencia-Chamorro, 2003; Alvarez-Jubete vd., 2009; Alvarez-Jubete vd., 2010).

Kinoanın mineral içeriği, diğer tahıllar gibi kepek tabakasında toplanmış olup diğer tahılların yaklaşık iki katı kadardır (Repo- CarrascoValencia ve Serna, 2011). Kinoa taneleri kalsiyum, magnezyum, fosfor, potasyum, demir, bakır, mangan ve çinko bakımından buğday, arpa ve misırdan daha zengindir (Koziol, 1992; ValenciaChamorro, 2003). Kinoa kepeği bu önemli mineraller açısından zengin olduğu için besinsel açı kolaylıkla kapatılabilmektedir (Alvarez-Jubete vd., 2009; Alvarez-Jubete vd., 2010).

Kinoa taneleri oldukça yüksek miktarda biyoaktif bileşikleri (polifenoller, saponinler flavonoidler ve fenolik asitler) özellikle kepek kısmında ihtiva etmektedir (Doğan ve Karwe, 2003; AlvarezJubete vd., 2010). Hemalatha vd. (2016) yapmış oldukları bir çalışmada kinoa kepeğinden elde edilen fenolik ekstraktların yüksek oranda antioksidan etkiye sahip olduğunu bildirmişlerdir. Kinoanın sahip olduğu bu biyoaktif bileşenlerin kan ve kolesterol seviyelerini düşürdüğü, kanser hücrelerinin gelişimini engellediği, toksinleri yok ettiği, bağışıklık sistemini güçlendirdiği ve kalp hastalıklarını önlediği bilimsel olarak ortaya konmuştur (Guzman-Maldonado ve ParedesLopez, 1998).
Kinoa kepeğinin ihtiva ettiği diyet lifi (çözünebilen ve çözünemeyen diyet lifleri) ile tokluk/gastrik boşalma üzerine, kan şekeri kontrolü ve insülin metabolizması, protein glikozilasyonu kolesterol ve trigliserit metabolizmasında farklı fizyolojik etkilere sahip olduğu bildirilmiştir. Kinoadan izole edilen karbonhidratlar yararlı hipoglisemik etkilere sahip olduklar1 ve serbest yağ asitlerinin indirgenmesine neden oldukları için kinoa nutrasötik bir gida kaynağı olarak düşünülebilir (James, 2009).

Bu nedenlerle sunulan bu çalışmada, yüksek lif ve mineral içeriğine sahip olan kinoa kepeği farklı boyutlarda öğütüldükten sonra bisküvi üretiminde un yerine kullanılmış olup, son ürünün fiziksel, tekstürel ve duyusal özellikleri incelenmiştir.

\section{Materyal}

Kinoa kepeği, Niğde Ömer Halisdemir Üniversitesi, Tarım Bilimleri ve Teknolojileri Fakültesi tarafindan Niğde ilinde yetiştirilmekte olan kinoalardan temin edilmiştir. Hasat edilen kinoaların kepek kısmı belirli ön işlemlerden geçirildikten sonra ögütülerek bisküvi yapımında hammadde olarak kullanılmıştır. Bisküvi üretiminde kullanılan diğer bileşenler Niğde ilindeki yerel marketlerden satın alınmıstır.

\section{Metot}

\section{Farklı Boyutlarda Kinoa Kepeği Eldesi}

Kinoa kepeğinin öğütülme işlemleri 0-500 dev/dk hız aralığında çalışabilen Standart-01 model dikey pinli karıştırmalı değirmende (Union Process, ABD) gerçekleştirilmiştir. Öğütme haznesi (0.75 L) seramikten yapılmış olup ürünün 1sınmaması için su ceketi ile donatılmıştır. Öğütme işlemin de $4 \mathrm{~mm}$ çaplı yoğunluğu $3.6 \mathrm{~g} / \mathrm{cm}^{3}$ olan alümina bilyeler kullanılmıştır. Kinoa kepeği karıştırmalıbilyeli değirmende öğütüldükten sonra, eleme işlemine tabi tutulmuştur. Bu işlem sırasında 1.18 $\mathrm{mm} ; 0.850 \mathrm{~mm} ; 0.420 \mathrm{~mm} ; 0.300 \mathrm{~mm} ; 0.212 \mathrm{~mm}$; $0.150 \mathrm{~mm} ; 0.106 \mathrm{~mm}$ ve $0.075 \mathrm{~mm}$ 'lik elekler kullanılmış olup sarsintılı elek makinası (Endecotts-Octagon 200, İngiltere) yardımıla farklı boyutlarda kinoa kepekleri elde edilmiştir. Eleme süresi (5 dk) sabit tutulmuștur. 


\section{Bisküvi Üretimi}

Bisküvi üretiminde AACC Standart Metod 10-54 (Anonim, 2001) kullanılmış olup bisküvi formülasyonundaki un içeriği \% 25 azaltılmış ve farklı tane boyutlarına sahip kinoa kepekleri eklenmiştir. Bu aşamada beş farklı parçacık boyutlu kinoa kepeği kullanılmıştır: 300-420 $\mu \mathrm{m}$ (K1), 212-300 $\mu \mathrm{m}$ (K2), 150-212 $\mu \mathrm{m}$ (K3), 106$150 \mu \mathrm{m}$ (K4) ve 75-106 $\mu \mathrm{m}$ (K5). Bisküvi üretiminde kullanilan malzemeler ve miktarları Çizelge 1'de sunulmuştur.

Çizelge 1. Bisküvi örneklerinin kodları ve formülasyonlar

Table 1. Biscuit samples codes and formulations

\begin{tabular}{lcccccc}
\hline $\begin{array}{l}\text { Ingrediyenler } \\
\text { Ingredients }\end{array}$ & $\begin{array}{c}\text { Kontrol } \\
\text { Control }\end{array}$ & K1 & K2 & K3 & K4 & K5 \\
\hline $\begin{array}{l}\text { Partikül Boyutu }(\mu \mathrm{m}) \\
\text { Particle siz̨e }(\mu \mathrm{m})\end{array}$ & - & $300-420$ & $212-300$ & $150-212$ & $106-150$ & $75-106$ \\
\hline $\begin{array}{l}\text { Bisküvilik Un }(\mathrm{g}) \\
\text { Wheat flour }(g)\end{array}$ & 80 & 60 & 60 & 60 & 60 & 60 \\
\hline $\begin{array}{l}\text { Kinoa kepeği }(\mathrm{g}) \\
\text { Qinoa bran }(g)\end{array}$ & - & 20 & 20 & 20 & 20 & 20 \\
\hline $\begin{array}{l}\text { Bisküvilik yağ }(\mathrm{g}) \\
\text { Shortening }(g)\end{array}$ & 32 & 32 & 32 & 32 & 32 & 32 \\
\hline $\begin{array}{l}\text { Sodyum bikarbonat }(\mathrm{g}) \\
\text { Sodium bicarbonate }(g)\end{array}$ & 1.2 & 1.2 & 1.2 & 1.2 & 1.2 & 1.2 \\
\hline $\begin{array}{l}\text { Pudra şekeri }(\mathrm{g}) \\
\text { Sugarpowder }(g)\end{array}$ & 33.6 & 33.6 & 33.6 & 33.6 & 33.6 & 33.6 \\
\hline $\begin{array}{l}\text { Tuz (g) } \\
\text { Sodium chloride }(g)\end{array}$ & 1 & 1 & 1 & 1 & 1 & 1 \\
\hline $\begin{array}{l}\text { Süt tozu (g) } \\
\text { Nonfat dry milk }(g)\end{array}$ & 0.8 & 0.8 & 0.8 & 0.8 & 0.8 & 0.8 \\
\hline $\begin{array}{l}\text { Su (mL) } \\
\text { Water (mL) }\end{array}$ & 18.6 & 25 & 25 & 25 & 25 & 25 \\
\hline
\end{tabular}

\section{Bisküvi Hamurunda Tekstürel Analizler}

Bisküvi hamurlarının tekstürel özelliklerinin belirlenmesinde TA.XTplus Texture Analyzer (İngiltere) cihazı kullanılmışır. Hamurların yapışkanlık ve elastiklik değerleri ölçümleri $6 \mathrm{~mm}$ $(\mathrm{P} / 6)$ silindirik prob kullanılarak $3.0 \mathrm{~mm} /$ saniye test hızında $20 \mathrm{~mm}$ derinliğe kadar yapılmıştır. Cam kap (8 cm çapında) içerisindeki hamur yüksekliği $5 \mathrm{~cm}$ olacak şekilde sabit tutulmuştur.

\section{Bisküvilerde Yayılma Oranı}

Bisküvi örneklerinin yayllma oranlarının hesaplanmasinda AACC Method No 10.54 (Anonim, 2001) metodundan yararlanılmış ve bisküvi örneklerinin genişlik/kalınlık oranı yayılma oranı olarak hesaplanmıştır.

\section{Bisküvilerde Renk Ölçümü}

Çalışmada üretilen bisküvilerin renk ölçümleri Minolta CR-400 cihazı (Konica Minolta Sensing,
Osaka, Japonya) ile CIE lab standardına göre gerçekleştirilmiştir.

\section{Bisküvilerde Tekstürel Analizler}

Bisküvi örneklerinin kırılganlık ve sertlik ölçümleri TA.XTplus Texture Analyzer cihazı kullanılarak yapılmışır. HDP/3PB 3-Point Bending Rig probu kullanilarak yapilan ölçümlerde $0.5 \mathrm{~mm} /$ saniye test hızı kullanılmıştır. HDP/3PB 3-Point Bending Rig probunun açıklı̆̆1 $6 \mathrm{~cm}$ olarak belirlenmiştir.

\section{Duyusal Analiz}

Farklı boyutlarda öğütülen kinoa kepeği ile üretilen bisküvilerinin duyusal değerlendirmesi Niğde Ömer Halisdemir Üniversitesi Gıda Mühendisliği öğretim elemanları ve öğrencilerinden oluşan 20 kişilik panelist grubu tarafından gerçekleştirilmiştir. Analize 
başlamadan önce panelistlere örnekler hakkında bilgi verilmiştir. Panelistler bisküvi örneklerini renk, tat, ağızda dağılabilirlik, koku, sertlik ve genel kabul edilebilirlik özelliklerine göre 5 puan üzerinden değerlendirmiştir. Örnekler arasında panelistlere su verilerek bir önceki örneğin etkisini ağızlarından kaldırmaları sağlanmıştır.

\section{Ístatistik Analiz}

Yapılan analizler sonucu elde edilen veriler, SPSS 15.0 paket programı kullanılarak istatistiki değerlendirmeye tabi tutulmuştur. Varyans analizi tekniği ile (ANOVA) grup ortalamaları arasındaki fark belirlenerek, bu farklillğın önem derecesi ise Duncan çoklu karşılaştırma testi yapilarak incelenmiştir $(P<0.05)$.

\section{BULGULAR VE TARTIŞMA}

Bisküvi hamurunun tekstürel özellikleri

Hamurun yapişkanlı̆̆ pişirmeden önce şekil vermede ve pişirme esnasinda da şekil bozukluğu olmaması açısından önemli bir parametredir. Şekil 1'de görüldüğü üzere kinoa kepeğinin boyutu azaldıkça hamurdaki yapısskanlık orantılı olarak azalmıştır. En düşük yapışkanlık değeri $(12.26 \mathrm{~g})$ ise en küçük boyutta kinoa kepeği (75-106 mm) kullanılan K5 örneğinde belirlenmiştir. Hamurun elastikiyet özelliği pişirilmeden önce uzayabilme kapasitesi için önemli bir parametredir. Şekil 2'de görüldüğü üzere kontrol örneğine benzer ve en yüksek elastikiyet değeri $(5.86 \mathrm{~mm})$ en büyük boyutta kinoa kepeği kullanılan K1 örneğinde belirlenmiştir. Kinoa kepeğinin boyutu azaldıkça hamurdaki elastikiyet önemli derecede azalmıstır (Şekil 2). Ancak K3, K4 ve K5 örneklerinin elastikiyet değeri istatistiki açıdan farklı bulunmamıştır $(P>0.05)$. Benzer sonuçlar bisküvi formülasyonunda farklı boyutlarda diyet lifi kullanılan bir doktora tez çalışması sonucunda da belirlenmiştir (Erinç, 2011).

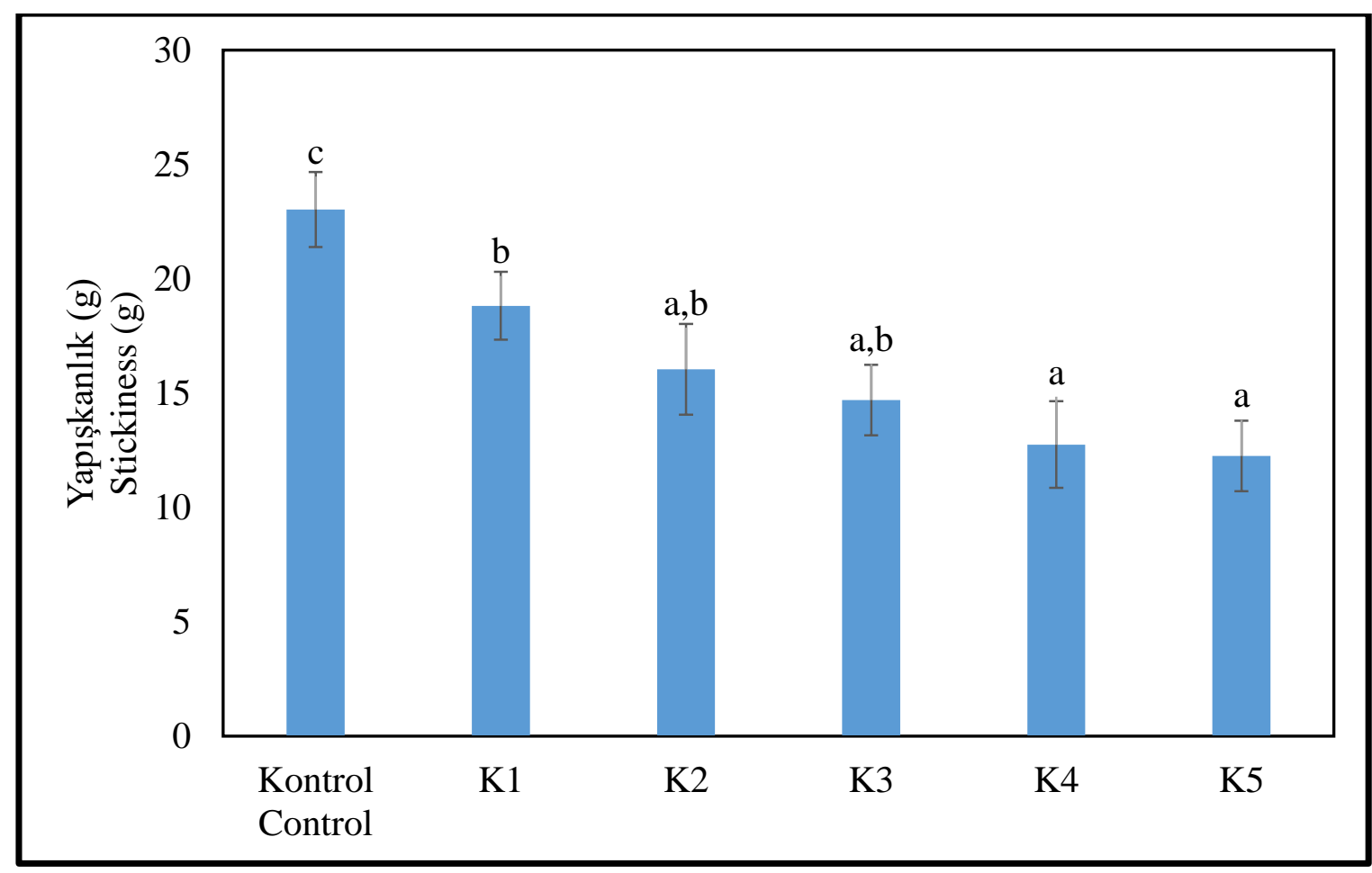

Şekil 1. Bisküvi hamurlarının yapışkanlık değerleri

Figure 1. Stickiness value of biscuit dough

a,b,c,d Farklı harflerle gösterilen ortalamalar istatiksel açıdan farklıdır $(P<0.05)$

a,b,c,d Different letters indicate significant differences between mean values at $P<0.05$ 


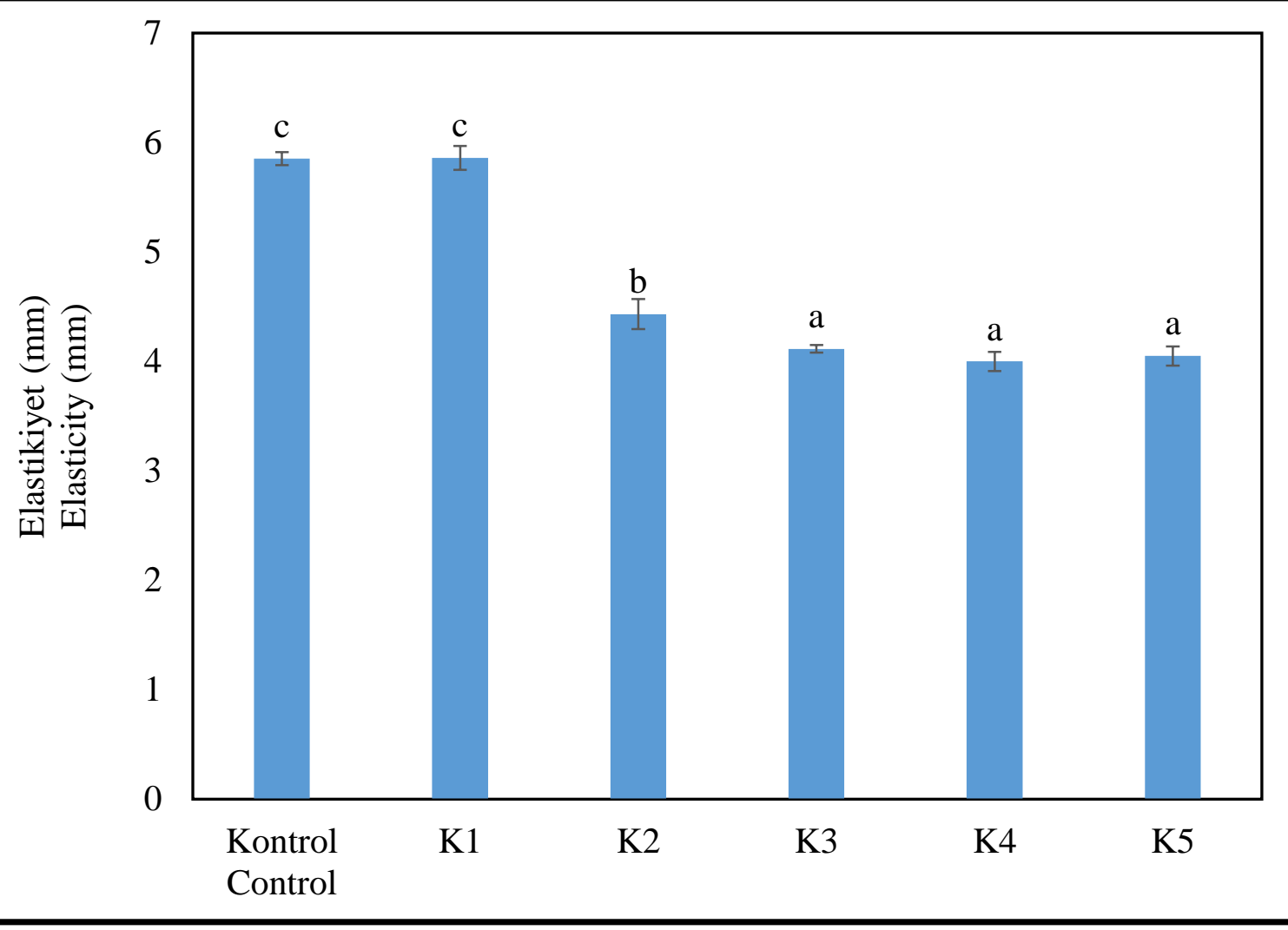

Şekil 2. Bisküvi hamurlarının elastikiyet değerleri

Figure 2. Elasticity of biscuit dough

a,b,c,d Farklı harflerle gösterilen ortalamalar istatiksel açıdan farklıdır $(P<0.05)$

a,b,c,d Different letters indicate significant differences between mean values at $P<0.05$

\section{Renk}

Gıdaların görünüş ve renk özellikleri gıda tüketilmeden önce tüketici beğenisini etkileyen ve g1da kalitesi hakkında bilgi veren önemli bir parametredir (Biernacka vd., 2017). Dış görünüş açısından yüzeyi en pürüzlü olan örnek en büyük boyutlu (300-420 $\mu \mathrm{m})$ kinoa kepeği içeren K1 örneğidir. Bunun nedeninin kinoa kepeğinin boyutunun çok büyük olmasından kaynaklandığ1 varsayılmışıtır (Şekil 3). Diğer örneklerin ise yüzeyi pürüzsüz olarak kabul edilmiştir.

Renk analizinde $a^{*}$ değeri kırmızılı̆̆ $(+)$ ve yeşilliği (-) göstermektedir. Üretilen bisküvilerdeki kinoa kepeği kullanımı ile kontrol örneğine göre $a^{*}$ değerinde bir azalma gözlenmiştir. Diğer taraftan kinoa kepeğinin boyutu azaldıkça son ürünlerin kırmızllığ artmıştır (Şekil 4). Ancak elde edilen veriler $\mathrm{a}^{*}$ değerinde istatistiki olarak bir fark olmadığını göstermektedir. Renk analizinde belirlenen $\mathrm{b}^{*}$ değeri $(+)$ sarlliğ1 ve $(-)$ maviliği göstermektedir. Analiz sonucunda belirlenen $\mathrm{b}^{*}$ değeri "+" olarak belirlenmiş olup ürünlerin sarıms1 olduğu gözlenmiştir. Şekil 5'de görüldüğü üzere bisküvi örneklerinde bisküvi unu yerine kinoa kepeği kullanıldığında $\mathrm{b}^{*}$ değerinin azaldığ1 ancak kepeğin boyutunun azalması ile $b^{*}$ değerinin artış gösterdiği tespit edilmiştir. L* değeri 0 (siyah) ile 100 (beyaz) arasındaki aydınlık derecesini ölçmektedir. Kinoa kepeğinin boyutuna bağlı olarak kontrol örneğine göre K3 örneğine kadar L* değerinde artış, daha küçük boyutlu kinoa kepeği kullanımda ise kontrol örneğinden yüksek olmakla birlikte bir azalma gözlemlenmiştir (Şekil 6). Sunulan bu çalş̧ma sonucunda farklı boyutlarda kinoa kepeği kullanılarak üretilen bisküvilerin $L^{*}$ değeri 60-67 aralığında, a* değeri 4.9-6.3 aralığında, b* değeri ise 28.0-31.5 aralığında belirlenmiștir. 


\section{H. Erinç}

Alaşalvar vd. (2019), tarafindan yapılan bir çalışmada, kinoa kepek ununun boyutlarının azalması ile kek örneklerinin iç $L^{*}$ değerlerinde istatistiksel olarak önemli bir azalma gözlenirken, $a^{*}$ ve b* değerlerinde artış gözlenmiştir. Ancak bu artışlar, $L^{*}$ değeri için 106-150 $\mu$, a ve b değerleri için 212-300 $\mu$ partikül boyutlarından sonra değişmemiştir. Alvarez-Jubete vd. (2009), kinoa ve diğer yalancı tahılların ekmeklerin kabuk renginde önemli derecelerde koyulaşmaya (düşük $\mathrm{L}$ değeri) neden olduğunu bildirmişlerdir.

$\mathrm{Bu}$ çalışmadan elde edilen veriler ve literatür sonuçlar1 göstermektedir ki zenginleştirme amaciyla bisküvilere ilave edilen materyallerin renk özellikleri, zenginleştirme amacıyla ilave edildikleri gıdanın da renk özelliklerini etkilemektedir.

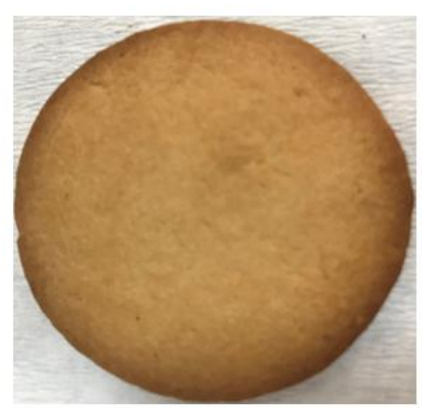

Kontrol Control

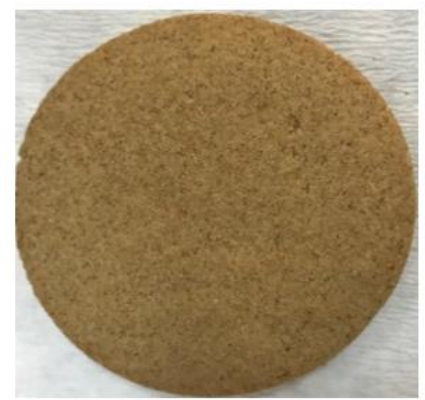

K3

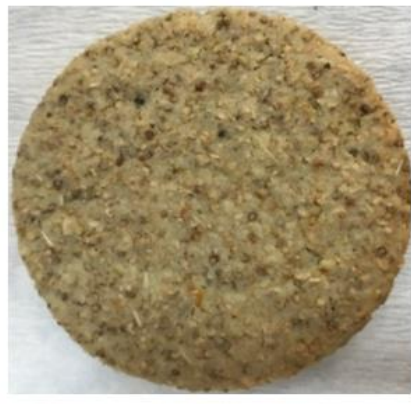

K1

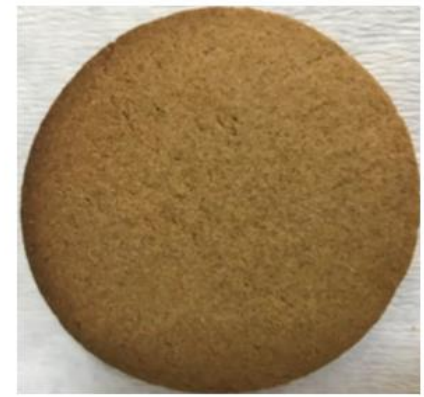

K4

Şekil 3. Bisküvilerin fotoğraflar1

Figure 3. Images of biscuits

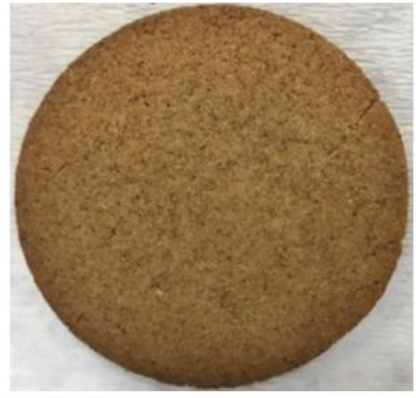

K2

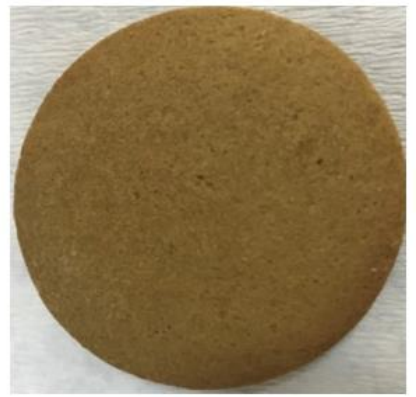

K5 


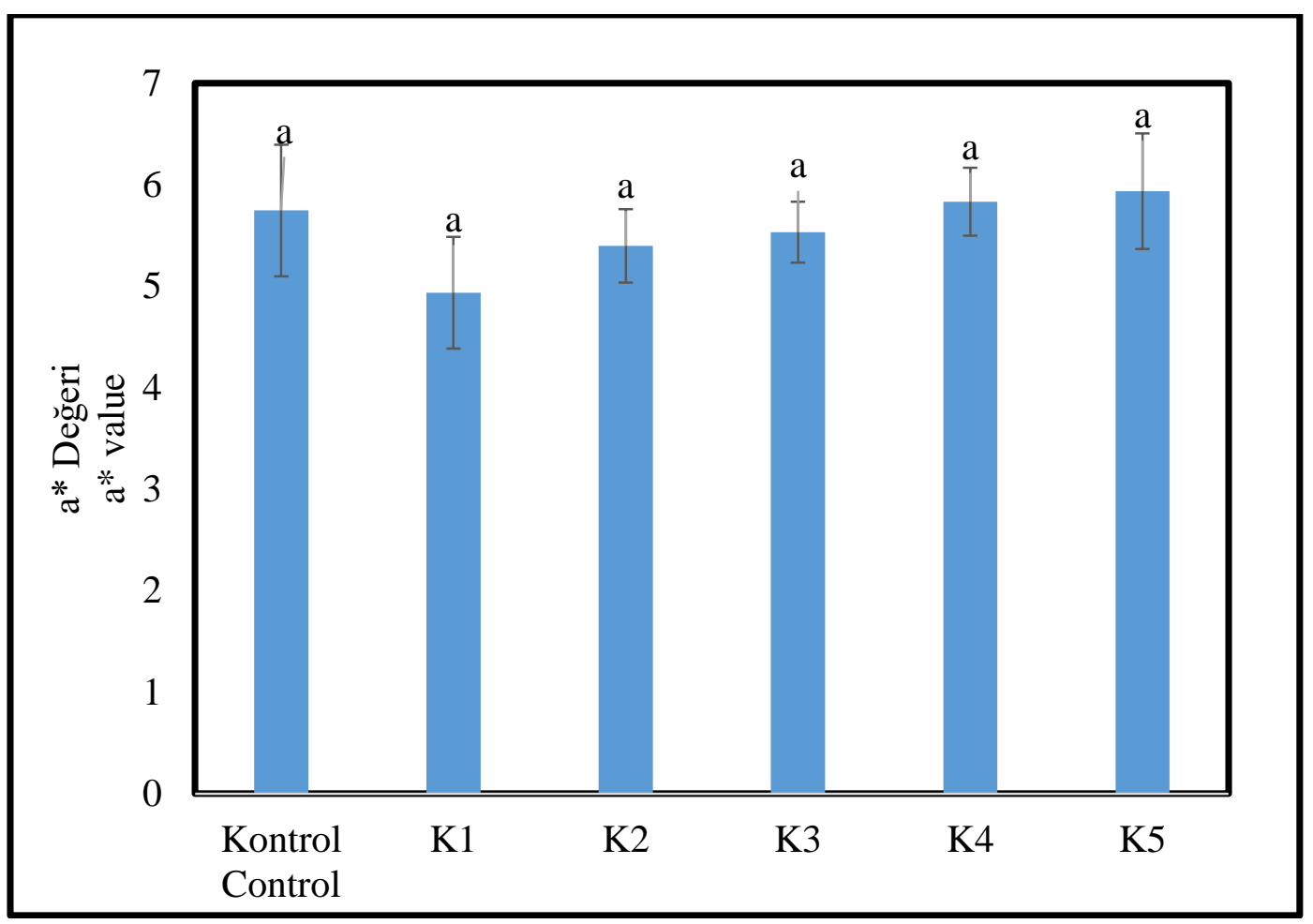

\section{Şekil 4. Bisküvilerin $\mathrm{a}^{*}$ değerì}

Figure 4. $a^{*}$ value of biscuits

a,b,c,d Farklı harflerle gösterilen ortalamalar istatiksel açıdan farklıdır $(P<0.05)$

a,b,c,d Different letters indicate significant differences between mean values at $P<0.05$

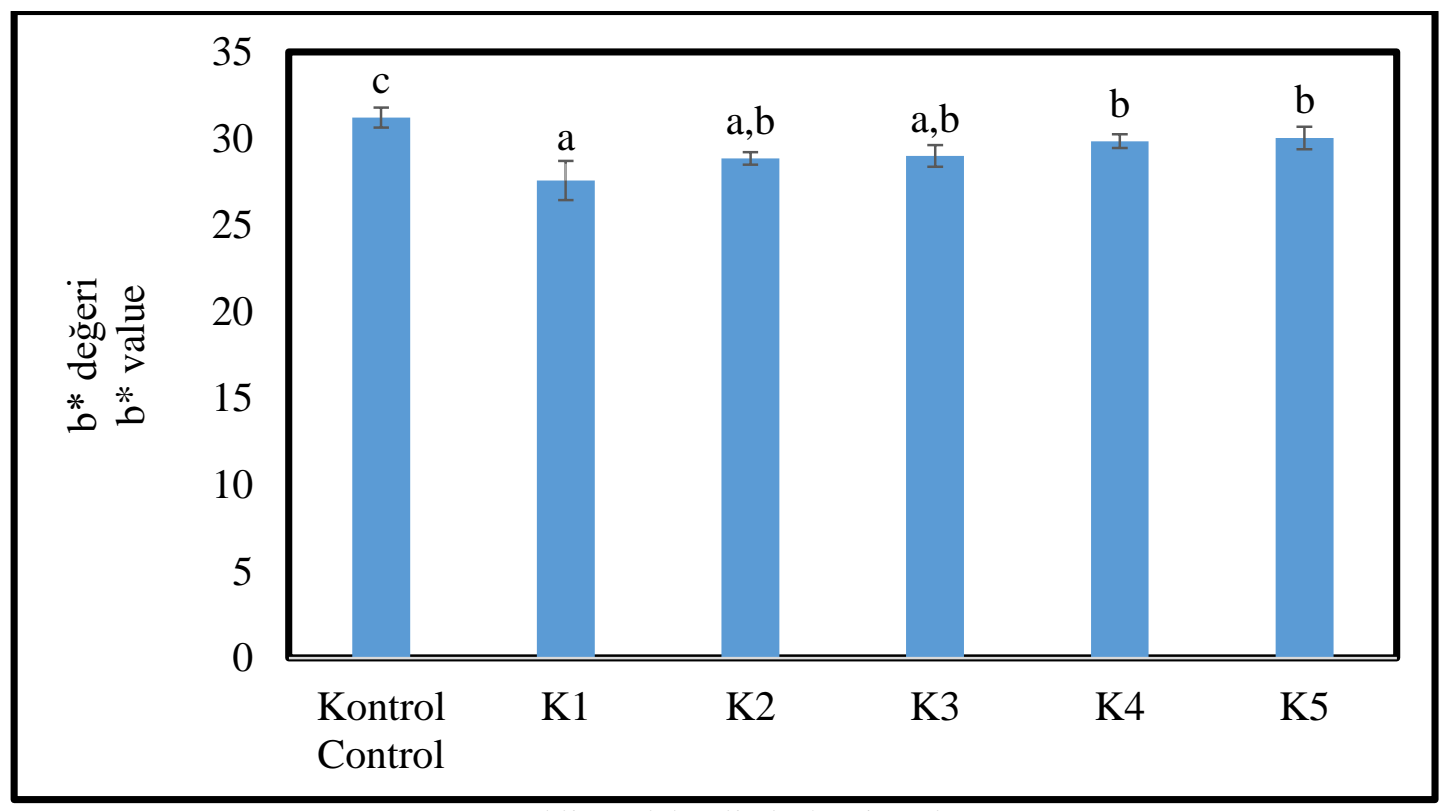

Şekil 5. Bisküvilerin $\mathrm{b}^{*}$ değeri

Figure $5 . b^{*}$ value of biscuits

a,b,c,d Farklı harflerle gösterilen ortalamalar istatiksel açıdan farklıdır $(P<0.05)$

a,b,c,d Different letters indicate significant differences between mean values at $P<0.05$ 


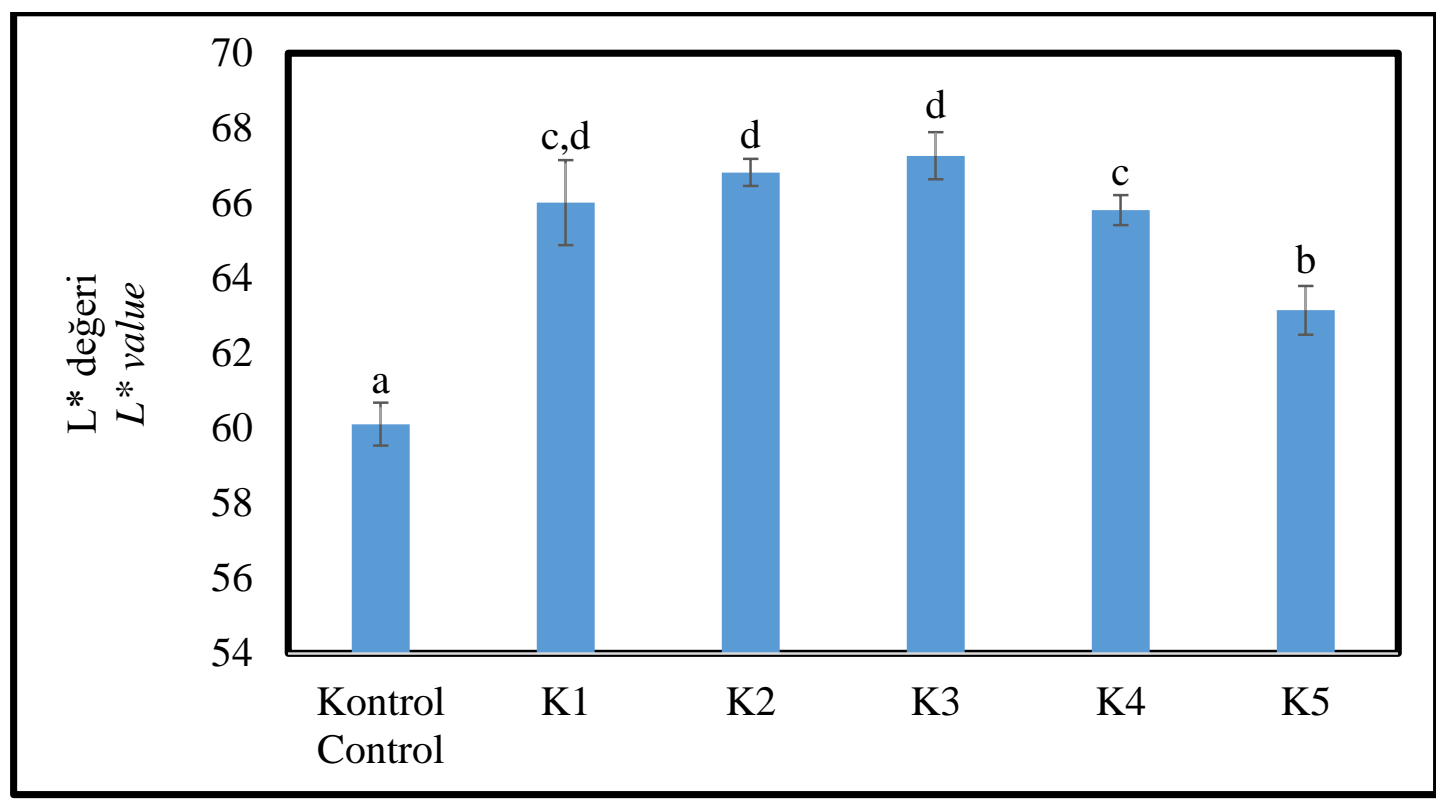

Şekil 6. Bisküvilerin $\mathrm{L}^{*}$ değeri

Figure 6. $L^{*}$ value of biscuits

a,b,c,d Farklı harflerle gösterilen ortalamalar istatiksel açıdan farklıdır $(P<0.05)$

a,b,c,d Different letters indicate significant differences between mean values at $P<0.05$

\section{Kuru Madde Sonuçları}

Kuru madde analiz sonuçlarına göre bisküvi örneklerine ilave edilen kinoa kepek ununun boyutlarının azalması ile örneklerin kuru madde içeriğinde istatistiksel olarak önemli bir artış meydana gelmiştir $\left(\begin{array}{ll}P & <0.05\end{array}\right)$. İstatistiksel değerlendirme sonucunda en büyük boyutlu kinoa kepek unu içeren K1 formülasyonu kontrol örneği ile aynı kuru madde özelliklerini göstermiştir (Şekil 7). Benzer sonuçlar Alaşalvar vd. (2019) tarafindan yapilan bir çalışma sonucunda da rapor edilmiştir. Ancak Erinç (2011), yapmiş olduğu çalışma sonucunda bisküvi formulasyonunda farklı boyutlarda diyet lifi kullanımı ile son ürünün kuru madde içeriğinin azaldığını belirlemisstir. Diğer taraftan Caperuto vd. (2001), yaptıklar1 glütensiz spagetti tipi makarnada, kinoa kepeği unu eklenmesinin pişirme suyuna geçen kuru madde miktarında azalmaya ve ağırllğıında ise artışa neden olduğunu bildirmişlerdir.
Bisküvilerin Sertlik ve Kırılabilirlik Özellikleri Sertlik, bisküvinin ilk 1sırışta dişe gösterdiği direnci ifade eder. Bisküvinin tat ile ilgili özelliklerinin ilk aşamasıdır. Bisküvinin dişe uyguladığ1 direncin çok veya az olması istenmez. Şekil 8'de görüldüğü üzere kontrol örneği ile kıyaslandığında bisküvi örneklerinin sertliğinin büyük boyutlu kinoa kepeği unu kullanımıyla azaldığı ancak boyutların azalmasıyla artış gösterdiği tespit edilmiştir $(P<0.05)$. Erinc vd. (2018) tarafindan yapılan çalışma sonucunda bisküvi örnekleri için ve Alaşalvar vd. (2019) tarafindan yapılan çalışma sonucunda kek örneği için benzer sonuçlar rapor edilmiştir. Alaşalvar vd. (2019), kinoa kepeği unu boyutlarına bağlı olarak kek örneklerinin sertliğinin \%3.5-30.4 oranında arttığını rapor etmişlerdir. Farklı boyutlarda armut posası kullanılarak üretilen kekler üzerine yapılan bir çalışmada, armut posasının partikül boyutunun azalması ile keklerin sertliğinde artış olduğu rapor edilmiştir (Rocha-Parra vd., 2019). 


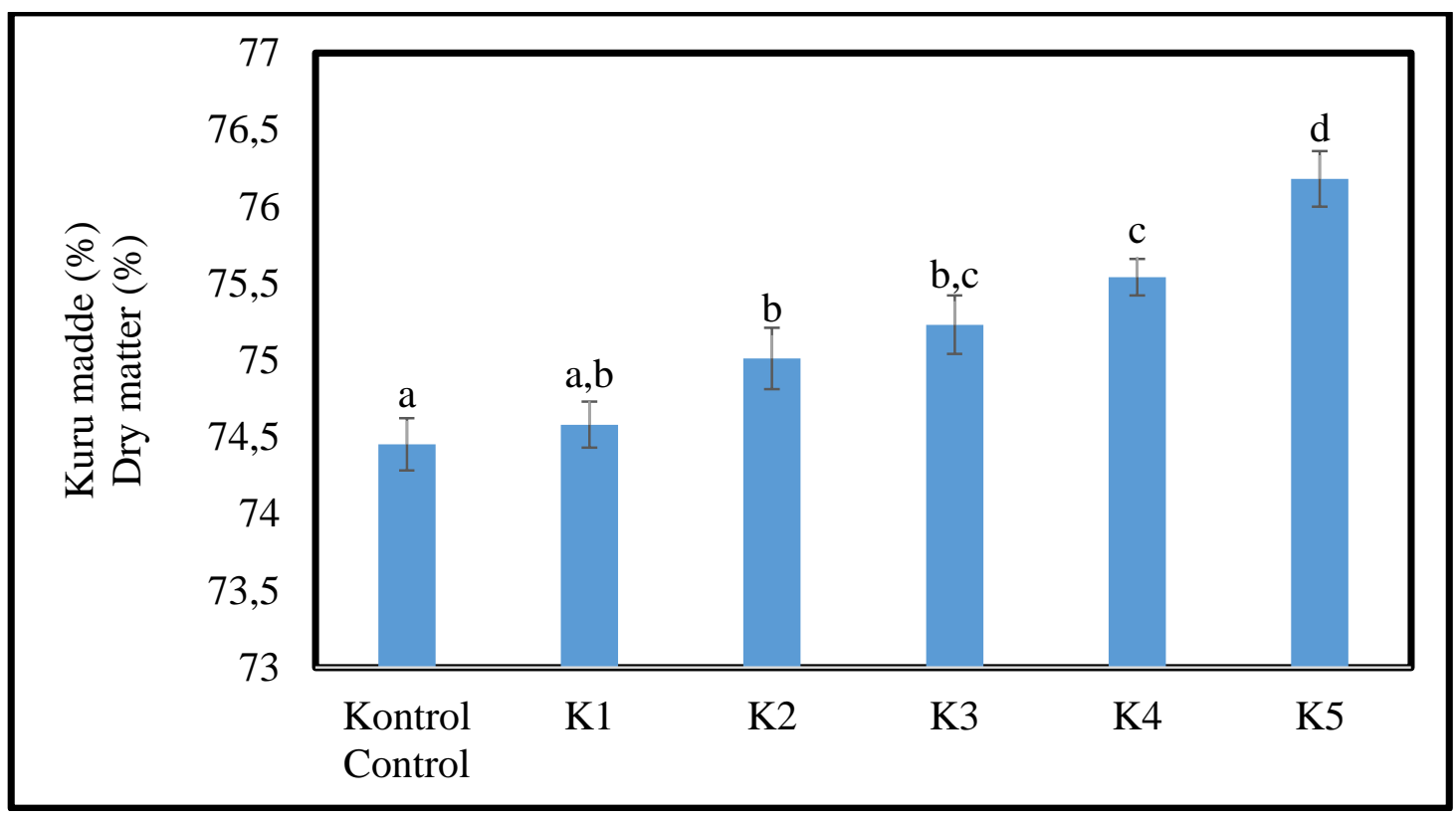

Şekil 7. Kuru madde içeriği

Figure 7. Dry matter content

a,b,c,d Farklı harflerle gösterilen ortalamalar istatiksel açıdan farklıdır $(P<0.05)$

a,b,c,d Different letters indicate significant differences between mean values at $P<0.05$

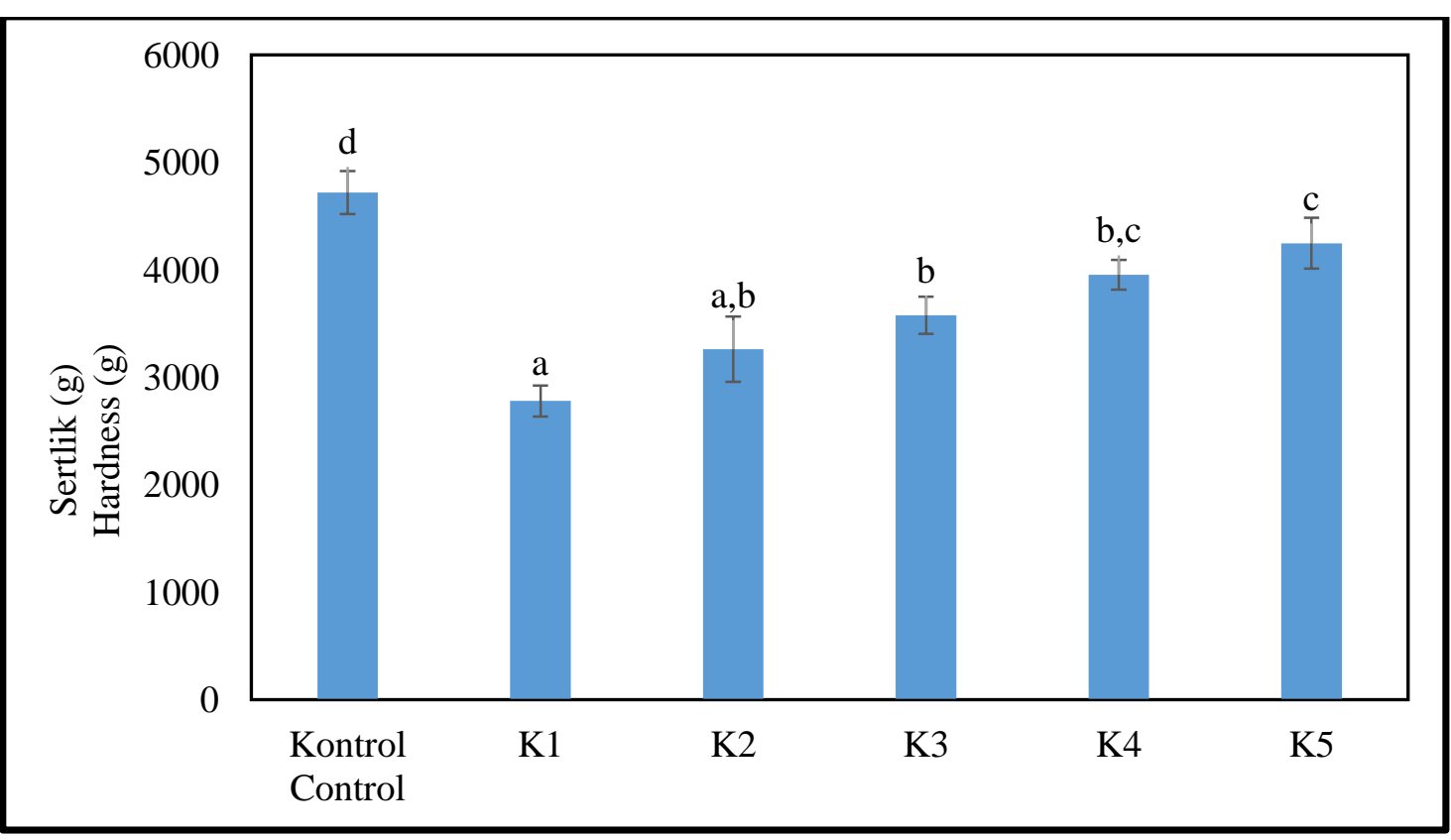

Șekil 8. Bisküvilerin sertlik değerleri

Figure 8. Hardness of biscuits

a,b,c,d Farklı harflerle gösterilen ortalamalar istatiksel açıdan farklıdır $(P<0.05)$

a,b,c,d Different letters indicate significant differences between mean values at $P<0.05$ 
Bisküvi ambalajlama ve nakliyede kırlmayacak kadar dayanıklı ancak 1sırma esnasinda da dağılacak bir kırılganlıkta olmalıdır. Elde edilen değerlerden görüldüğü üzere bisküvi örneklerinde kullanılan kinoa kepeğinin boyutu azaldıkça kırılabilirlik değeri $(\mathrm{mm})$ artmıs yani kırılma için gerekli mesafe arttı̆̆ından daha esnek hale gelmiştir (Şekil 9). Kırılma için gerekli mesafenin artmas1 ürünün elastikiyetinin artmas1 yani kırllganlığının azalması anlamına gelmektedir. Benzer sonuçlar buğday kepeği lifi kullanılan Erinc vd. (2018) tarafindan yapılan çalışma sonucunda da rapor edilmiştir.

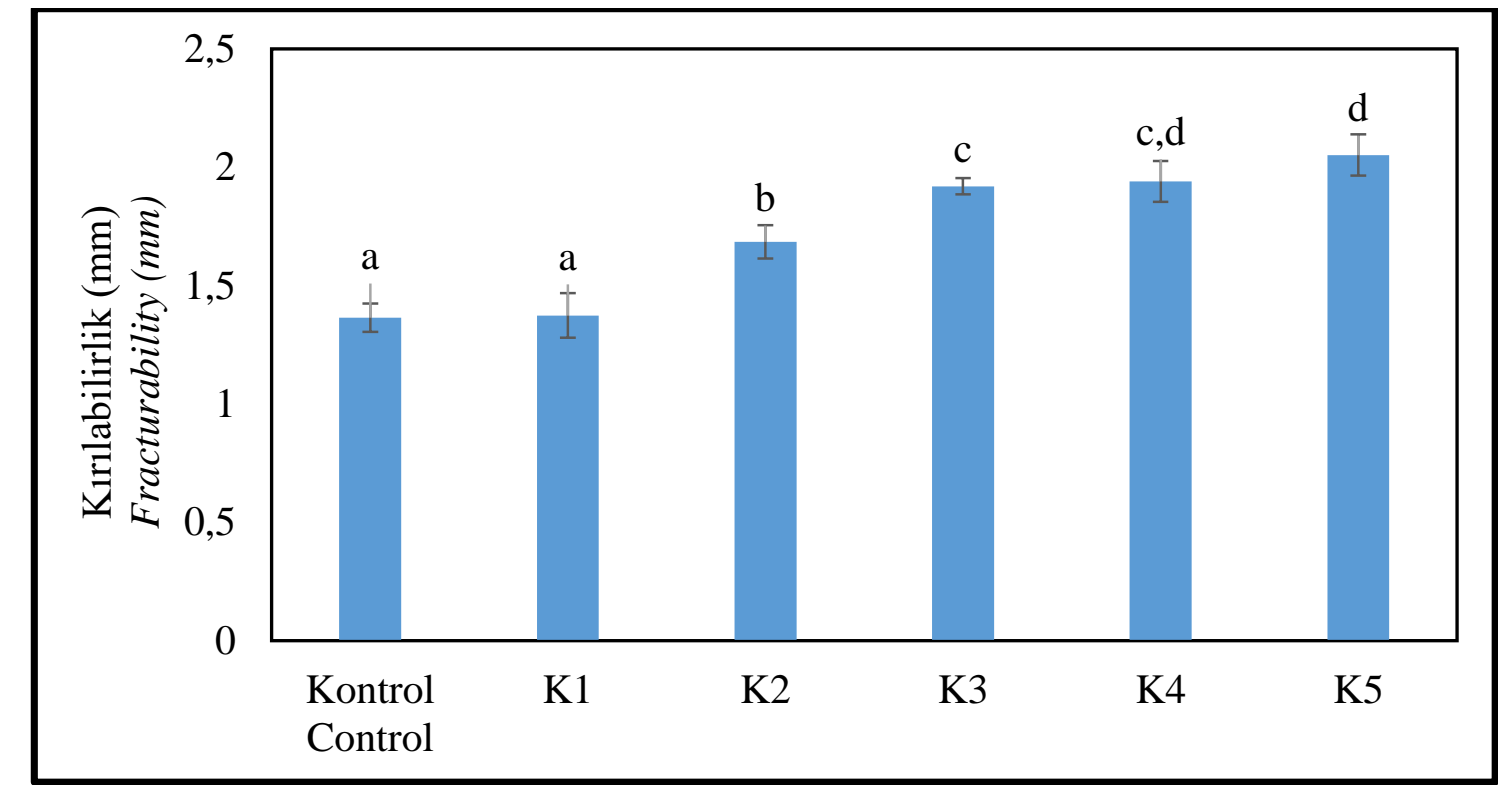

Şekil 9. Bisküvilerin kırılabilirlik değerleri

Figure 9. Fracturability of biscuits

a,b,c,d Farklı harflerle gösterilen ortalamalar istatiksel açıdan farklıdır $(P<0.05)$

a,b,c,d Different letters indicate significant differences between mean values at $P<0.05$

Sunulan bu çalışma sonucunda kinoa kepekli bisküvi üretiminde yapılan kontrol bisküvisinin sertlik değeri $4720.23 \mathrm{~g}$, kırılabilirlik değeri 1.37 mm, K1 bisküvi örneklerinin sertlik değeri $2781.06 \mathrm{~g}$, kırılabilirlik değeri $1.37 \mathrm{~mm}$, K2 bisküvi örneklerinin sertlik değeri 3263.52 g, kırılabilirlik değeri $1.69 \mathrm{~mm}$, K3 bisküvi örneklerinin sertlik değeri $3578.41 \mathrm{~g}$, kırılabilirlik değeri $1.92 \mathrm{~mm}$, K4 bisküvi örneklerinin sertlik değeri $3954.68 \mathrm{~g}$, kırllabilirlik değeri $1.94 \mathrm{~mm}$, ve en küçük boyutlu kinoa kepeği içeren K5 bisküvi örneklerinin ise sertlik değeri $4249.48 \mathrm{~g}$ ve kırılabilirlik $2.05 \mathrm{~mm}$ olarak belirlenmiştir.

\section{Yay1lma Oran1}

Bisküvi örneklerinin genişlik/kalınlık oranları yayılma oranı olarak hesaplanmıştır. Yapılan hesaplamalara göre kontrol ve K1 örneğinden sonra yayılma oranının azaldığ ve K3-K5 arasında sabit kaldığ1 gözlemlenmiştir (Şekil 10). Benzer sonuçlar Erinc vd. (2018) tarafindan yapilan çalsşma sonucunda ve Erinç (2011) tarafindan da rapor edilmiştir. Kullanılan kepeğin boyutuna bağlı olarak bisküviyi yayılmaya karşı bir arada tuttuğu anlaşılmaktadır. Sunulan bu çalışma sonucunda kontrol bisküvisinin yayılma oranı 5.85, K1 bisküvi örneklerinin sert yayılma oran1 5.86, K2 bisküvi örneklerinin yayılma oran1 4.43 , K3 bisküvi örneklerinin yayılma oranı 4.12, K4 bisküvi örneklerinin yayllma oran1 4.00, ve en küçük boyutlu kinoa kepeği içeren K5 bisküvi örneklerinin yayılma oranı ise 4.05 olarak belirlenmiştir. 


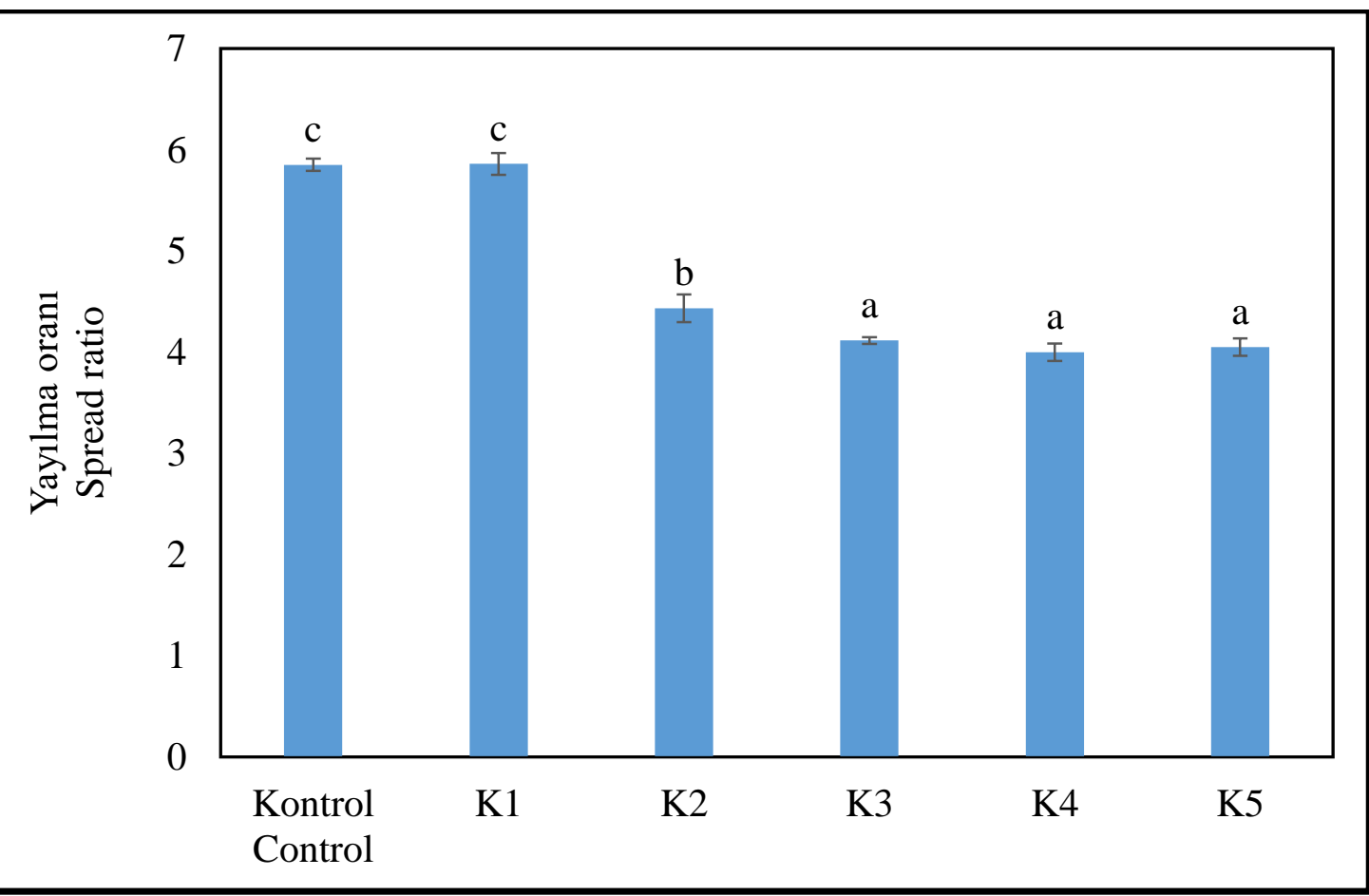

Şekil 10. Bisküvilerin yayılma oranı

Figure 10. Spread ratio of biscuits

a,b,c,d Farklı harflerle gösterilen ortalamalar istatiksel açıdan farklıdır $(P<0.05)$

a,b,c,d Different letters indicate significant differences between mean values at $P<0.05$

\section{Duyusal Analiz Sonuçları}

Bisküvi örneklerinin duyusal analiz sonuçları Çizelge 2'de verilmiştir. Bisküvilerin tüm duyusal özellikleri bakımından en beğenilen örnek kontrol örneği olmuştur. Kinoa kepek unu ilave edilen örneklerin rengi panelistler tarafindan daha az beğenilmiş, ancak, farklı partikül boyutlarının renk üzerinde farklılık yaratmadığ1 görülmüştür $(P$ $>0.05)$. Benzer durum tat, ağızda dağılabilirlik ve koku özellikleri içinde görülmüştür. Ağızda dağılabilirlik açısında en az beğenilen örnek 4.0 puanlı K5 örneği olmasına rağmen, istatistiksel olarak diğer partikül boyutlarından farklı olmadığ1 şeklinde değerlendirilmiştir. Duyusal analizde bisküvilerin sertliğinin kinoa kepek unu ilavesi ile arttığı bu nedenle beğenilmediği belirlenmiştir. Tekstürel sertlik ölçümünde sertlik değeri kontrole en yakın olan örnek K5 olmasına rağmen duyusal analizde birbirinden en farklı puanı alan örnekler, kontrol ve K5 olmuştur. Bunun nedeni tam olarak açıklanamasa da duyusal analizde örneğin ağıza alındıktan sonra tekrar tekrar 1sırılması nedeniyle tekstürel analizden farklı sonuç alındığı varsayllmıştır.

Bisküvi örnekleri genel beğeni puanları incelendiğinde en beğenilen örnek kontrol örneği, en az beğenilen ise $\mathrm{K} 5$ örneği olmuştur. Chlopicka vd. (2012), kinoa, karabuğday ve amarant unları kullanarak ekmekler yapmış ve ekmeklerin duyusal özelliklerini incelemişlerdir. Elde ettikleri sonuçlara göre, ekmeklerin renk ve konsistens özelliklerini, kullanılan yalancı tahıllar arasında en olumsuz etkileyen kinoa unu olmuş, panelistlerin \%30'u kinoa unlu ekmeğin tat olarak kabul edilebileceğini, \%15' $\mathrm{i}$ ise kabul edilemez olduğunu belirtmişlerdir. Benzer şekilde, kinoa kepeği unu katılarak yapılan misır unlu glütensiz spagetti makarnaların panelistlerin beğenisi orta düzeyde bulunmuştur (Caperuto vd., 2001). Alaşalvar vd. (2019), kinoa kepeği katkılı keklerin genel beğeni özelliklerinin buğday unundan yapılan keklere göre olumsuz etkilendiğini rapor etmişlerdir. Kinoa kepek unu ve farklı boyutlarının kullanımı genel beğeni özelliklerini olumsuz bir şekilde etkilemiştir. 
Çizelge 2. Farklı boyutlarda kinoa kepeği unu kullanılarak yapılan bisküvilerin duyusal değerlendirme sonuçlar1

Table 2. Sensory evaluation results of biscuits made using quinoa brans of different size

\begin{tabular}{lcccccc}
\hline Kalite Kriterleri & $\begin{array}{c}\text { Kontrol } \\
\text { Control }\end{array}$ & K1 & K2 & K3 & K4 & K5 \\
\hline $\begin{array}{l}\text { Renk } \\
\text { Color }\end{array}$ & $4.8 \pm 0.2^{\mathrm{a}}$ & $4.2 \pm 0.5^{\mathrm{a}}$ & $4.2 \pm 0.3^{\mathrm{a}}$ & $4.2 \pm 0.5^{\mathrm{a}}$ & $4.2 \pm 0.5^{\mathrm{a}}$ & $4.3 \pm 0.5^{\mathrm{a}}$ \\
$\begin{array}{l}\text { Tat } \\
\text { Taste }\end{array}$ & $4.8 \pm 0.3^{\mathrm{a}}$ & $4.1 \pm 0.3^{\mathrm{a}}$ & $4.2 \pm 0.2^{\mathrm{a}}$ & $4.2 \pm 0.5^{\mathrm{a}}$ & $4.3 \pm 0.3^{\mathrm{a}}$ & $4.1 \pm 0.5^{\mathrm{a}}$ \\
Ağıda Dağ1labilirlik & $4.5 \pm 0.2^{\mathrm{a}}$ & $4.1 \pm 0.3^{\mathrm{a}}$ & $4.1 \pm 0.5^{\mathrm{a}}$ & $4.1 \pm 0.5^{\mathrm{a}}$ & $4.1 \pm 0.5^{\mathrm{a}}$ & $4.0 \pm 0.5^{\mathrm{a}}$ \\
$\begin{array}{l}\text { Dispersibility in mouth } \\
\text { Koku }\end{array}$ & $4.5 \pm 0.2^{\mathrm{a}}$ & $4.5 \pm 0.2^{\mathrm{a}}$ & $4.7 \pm 0.5^{\mathrm{a}}$ & $4.4 \pm 0.5^{\mathrm{a}}$ & $4.5 \pm 0.5^{\mathrm{a}}$ & $4.2 \pm 0.5^{\mathrm{a}}$ \\
$\begin{array}{l}\text { Smell } \\
\text { Sertlik }\end{array}$ & $4.5 \pm 0.5^{\mathrm{b}}$ & $4.0 \pm 0.2^{\mathrm{b}}$ & $4.1 \pm 0.5^{\mathrm{b}}$ & $4.3 \pm 0.5^{\mathrm{b}}$ & $4.1 \pm 0.5^{\mathrm{b}}$ & $2.3 \pm 0.5^{\mathrm{a}}$ \\
$\begin{array}{l}\text { Hardness } \\
\text { Genel kabul edilebilirlik }\end{array}$ & $4.8 \pm 0.5^{\mathrm{b}}$ & $4.0 \pm 0.5^{\mathrm{b}}$ & $4.4 \pm 0.5^{\mathrm{b}}$ & $4.2 \pm 0.5^{\mathrm{b}}$ & $4.3 \pm 0.5^{\mathrm{b}}$ & $2.1 \pm 0.5^{\mathrm{a}}$ \\
General acceptability & & & & & \\
\hline
\end{tabular}

a,b,c,d Aynı satırda farklı harflerle gösterilen ortalamalar istatiksel açıdan farklıdır $(P<0.05)$

a,b,c,d Different letters in the same rows indicate significant differences between mean values at $P<0.05$

\section{SONUÇ}

Bu çalışmada farklı boyutlarda kinoa kepeği kullanılarak, laboratuvar ortamında bisküvi üretimi yapılmış ve farklı boyutlarda kinoa kepeğinin bisküvilerin fizikse, tekstürel ve duyusal özelliklerine olan etkisi incelenmiştir. Elde edilen verilere göre, kinoa kepek unu boyutuna bağl1 olarak bisküvilerin karakteristiklerinde önemli değişimler meydana getirmektedir. Çalışma sonucunda kinoa kepeğinin sağlıklı beslenen bireyler için yeni bir alternatif hammadde olarak bisküvi üretiminde kullanılabileceği sonucuna varılmıştır. Kinoa kepekli ürün tüketiminin artması, ihtiyaç duyulması ile kinoanın ülke genelinde üretimi ve tüketiminin artması da beklenmektedir.

\section{ÇIKAR ÇATIŞMASI BEYANI}

Yazarın, başka kişiler ve/veya kurumlar ile çıkar çatışması bulunmamaktadır.

\section{KAYNAKLAR}

Alaşalvar, H., Erinç, H., Çolakoğlu, A.S. (2019). Farklı boyutlarda kinoa kepek unu kullanımının keklerin fiziksel, duyusal ve tekstürel özellikleri üzerine etkisi. KSÜ Mühendislik. Bilimleri Dergisi, 22:139-145.

Alvarez-Jubete, L., Arendt, E. K., Gallagher, E. (2009). Nutritive value and chemical composition of pseudocereals as gluten-free ingredients. International Journal of Food Sciences and Nutrition, 60(4): 240-257.

Alvarez-Jubete, L., Wijngaard, H., Arendt, E.K., Gallaghera, E. (2010). Polyphenol composition and in vitro antioxidant activity of amaranth, quinoa buckwheat and wheat as affected by sprouting and baking. Food Chemistry, 119(2):770778.

Anonim (2001). Approved Methods of American Association of Cereal Chemists. American Association of Cereal Chemists, St. Paul, MN.

Biernacka, B., Dziki, D., Gawlik-Dziki, U., Różyło, R., Siastała, M. (2017). Physical, sensorial, and antioxidant properties of common wheat pasta enriched with carob fiber. LWT -Food Science and Technology, 77:186-192.

Caperuto, L. C., Amaya-Farfan, J., Camargo, C.R.O. (2001). Performance of quinoa (Chenopodium quinoa Willd) flour in the manufacture of gluten-free spaghetti. Journal of the Science of Food and Agriculture, 81:95-101.

Chlopicka, J., Pasko, Gorinstein, S., Jedryas, A., Zagrodzkia, P. (2012). Total phenolic and total flavonoid content, antioxidant activity and sensory evaluation of pseudocereal breads. $L W T$ - Food Science and Tecbnology, 46, 548-555. 
Doğan, H., Karwe, M.V. (2003). Physicochemical properties of quinoa extrudates. Food Science and Technology International, 9(2):101-114.

Erinc, H., Mert, B., Tekin, A. (2018). Different sized wheat bran fibers as fat mimetic in biscuits: its effects on dough rheology and biscuit quality, J Food Sci Technol, 55(10):3960-3970.

Erinç, H. (2011). Bitkisel artıklardan farklı boyutlarda lif üretimi ve düşük yağlı ürünlerde kullanımı. Doktora tezi, Fen Bilimleri Enstitüsü, Ankara Üniversitesi, Türkiye.

Guzman-Maldonado, S.H., Paredes-Lopez, O. (1998). Functional products of plants indigenous to Latin America: Amaranth, quinoa, common beans and botanicals. Functional Foods: Biochemical and Processing Aspects. Lancaster: Technomic Publishing Company.

Hemalatha, P., Bomzan, D.P., Rao, B.S., Sreerama, Y.N. (2016). Distribution of phenolic antioxidants in whole and milled fractions of quinoa and their inhibitory effects on $\alpha$-amylase and $\alpha$-glucosidase activities. Food Chemistry, 199:330-338.

James, L.E.A. (2009). Quinoa (Chenopodium quinoa Willd.): composition, chemistry, nutritional, and functional properties. Advances in Food and Nutrition Research, 58:1-31.

Koyun S. (2013). Güvenli G1da: QUINOA (Chnopodium quinoa Wild.). Mesleki Bilimler Dergisi, 2(2):85-88.

Koziol, M.J. (1992). Chemical composition and nutritional evaluation of quinoa (Chenopodium quinoa Willd.). Journal of Food Composition and Analysis, 5(1): 35-68.

Repo-Carrasco-Valencia, R.A.M., Serna, L.A. (2011). Quinoa (Chenopodium quinoa, Willd.) as a source of dietary fiber and other functional components. Food Science and Technology (Campinas), 31(1):225-230.

Rocha-Parra, A. F., Belorio, M., Ribotta, P. D., Ferrero, C., Gómez, M. (2019). Effect of the particle size of pear pomace on the quality of enriched layer and sponge cakes. International Journal of Food Science \& Technology, 54: 1265- 1275.

Valencia-Chamorro S.A. (2003). Quinoa. Encyclopedia of Food Science and Nutrition. Amsterdam: Academic Press. 